\title{
Utilization of Storm Water Management Model for Urban Flood Scenario
}

\author{
D. Girish, Sunny Agarwal
}

\begin{abstract}
Majors cities in India have witnessed huge floods from past few decades. Due to rapid population growth and improper urban planning the chances of creek, localised or flash urban floods have drastically increased. Climatic changes are also a key reason for heavy rainfall that increases the flood volume and depth in a catchment. Modelling of Storm water plays a key role in estimating flood runoff quantity and quality. To check these issues SWMM is used to simulate floods scenario in Urban areas. This hydrological study is carried out to simulate and understand the rainfall runoff characteristics of the study area by using SWMM. It is an effective tool used for simulating flash floods and runoff in urban areas. In this study catchments have been subdivided into 14 parts and modelled for year 2017 rainfall events of 1-hr interval. The present study area is evaluated by importing AutoCAD map of the area in SWMM. Further Rainfall Data is imported as time series in the model. The results depict that the Runoff for the Sub catchments of S1, S2, S3, S9, S13 blocks are maximum. The study states that no nodes are flooded and also no overflow sections. Thus, the selected study area storm network system has been well planned and has enough carrying capacity to carry the simulated rainfall for a prolonged duration.
\end{abstract}

Keywords: AutoCAD, Flash Floods, Scenario, Sub catchments, SWMM.

\section{INTRODUCTION}

Urban Flooding is one of the most acute problem prevalent in the existing society. Many Indian cities are facing flash floods due to extreme rainfall event [1]. Well planned cities/towns are less likely to face the risk due to storm water flooding, but the problem arises in unplanned cities. Due to the rapid increase of industrialization and urbanization there is a tremendous loss of pervious land surface, which leads to increase in surface runoff and overflow [2]. This has cause enormous loss to the society in terms of life and property. Climatic changes are also a key reason for heavy rainfall that increases the flooding problem [3]. Most of the cities are unplanned, by considering into these issues there should be proper planning for the outlet of storm water [4]. In this context, there is an urgent call for the improvement and

Revised Manuscript Received on December 30, 2019.

* Correspondence Author

D. Gisrish*, B.Tech, Department of Civil Engineering Koneru Lakshmaiah Education Foundation, Vaddeswaram, Guntur, Andhra Pradesh, India - 522502.

Sunny Agarwal, Assistant Professor, Department of Civil Engineering Department, Koneru Lakshmaiah Education Foundation, Vaddeswaram, Guntur, Andhra Pradesh, India - 522502.

(C) The Authors. Published by Blue Eyes Intelligence Engineering and Sciences Publication (BEIESP). This is an open access article under the CC BY-NC-ND license (http://creativecommons.org/licenses/by-nc-nd/4.0/) upgradation of the drainage system design to check the failure of sewage system, gullies, manholes etc [5].

In 2017 due to the heavy rainfall, flash flooding situation prevails in Chennai which resulted in great financial loss and business, trade was affected deeply and many employment opportunities are lost. From these issues there is awareness about land use planning policy and flood risk management to safeguard the community with respect to the urban flooding. According to the EN 752 (European Standard) the design of drainage system should withstand for about 10 to 15 years of service depending upon traffic infrastructure [6].

There are many reasons for urban flooding like solid waste blocking in pipes/conduits, storm water carrying capacity is low, encroachment of canals/water bodies. From these, there should be a protection for urban areas, because these are the economic and trade centers which tend to change the fate of one's own financial status [7]. Due to urban flooding there is lots of damage to infrastructure and also loss of human lives, property, causes of epidemic diseases. Hence, proper analysis of storm network and flood management is required in urban areas to forecast flash flood conditions [8].

Designing of drainage system can be done by some hydrologic and hydraulic models like MIKE Flood, SWMM, MIKE URBAN etc. SWMM model is used to simulate the flood volume through its one-dimensional flood routing characteristic [9]. In case of MIKE URBAN model the two dimensional flow routing can be done during an extreme rainfall event occurring in short period which results in the flooding of drainage [10]. Roughness of the channel, slope and flow network plays a crucial role in building model in SWMM [11].

There are two types of estimation methods. In the physical parameter method DEM (Digital Elevation Model) data was deducted by spatial and geometry tools in Geographic Information System like Area, Width, Slope, Imperviousness, Depression Storage, Max Infiltration rate, Min Infiltration rate, Decay Coefficient [12]. Area, width, Slope are computed and in the hydrological parameter method, land cover in urban areas experimental values are determined by using Remote sensing image Imperviousness, Depression storage, Infiltration rate are computed from the hydrological parameters by Remote sensing [13].

In hydraulic module SWMM is used in simulating the sub catchments through main conduit where storm water is linked through these sub catchments. In the calibration process both the hydraulic and hydrological module are performed by Genetic Algorithm which is implemented by GANetXI [14]. From these parameters it is observed that by using Visual basic Application model, GANetXl and EPA SWMM, the calibration for such a giant drainage system are satisfied in case of peak volumes [15]. 
In this SWMM model rainfall runoff is evaluated and the behavior of flood water flow though drains and pipes.

In HEC-RAS, which is a hydraulic model generally used in simulation of heavy rainfall events including flash floods and also to determines the water flow through open channels [16]. For evaluating normal elevation level for drainage network, terrain model HAND is used in calibrating of low-lying areas [17].

Arc SWAT (Soil and Water Assessment Tool) which is a tool in ArcGIS software is used for watershed modelling [18]. For computing runoff rate from rainfall, Soil Conservation Service (SCS) curve number (CN) method also can be used [19]. ArcGIS based modeling with the help of Digital Elevation Model, Contour map model was simulated for Krishna Delta Andhra Pradesh [20]. Another attempt was made to estimate the flood and surface runoff with real time through GIS and Remote sensing for Krishna river, here discharge of flood from daily runoff is calculated by depth of runoff obtained from the SCS method [21].
For calculating runoff for Sarada river basin MNRCS-CN method is used, here various hydrological details like rainfall, land use, soil information, land cover were considered in MNRCS method. Depth of runoff was also computed by using IRS-P4-LISS IV. Land use and Land cover patterns are interpreted using ERDAS IMAGINE software [22]. In case of estimating rainfall runoff, optimal Manning's roughness coefficient is used from Genetic Algorithm [23]. In this study the model provides information about roughness coefficient, the performance is tested by Correlation coefficient (r) and Nash Sutcliffe Efficiency (NSE) [24].

Predicting frequency of flood, Gumbel's, Hazen's, California methods are used for Prakasam barrage at Vijayawada. From the results it is obtained that discharge from the barrage for next 20 years is 1823 TMC these are generated from Gumbel's method [25].

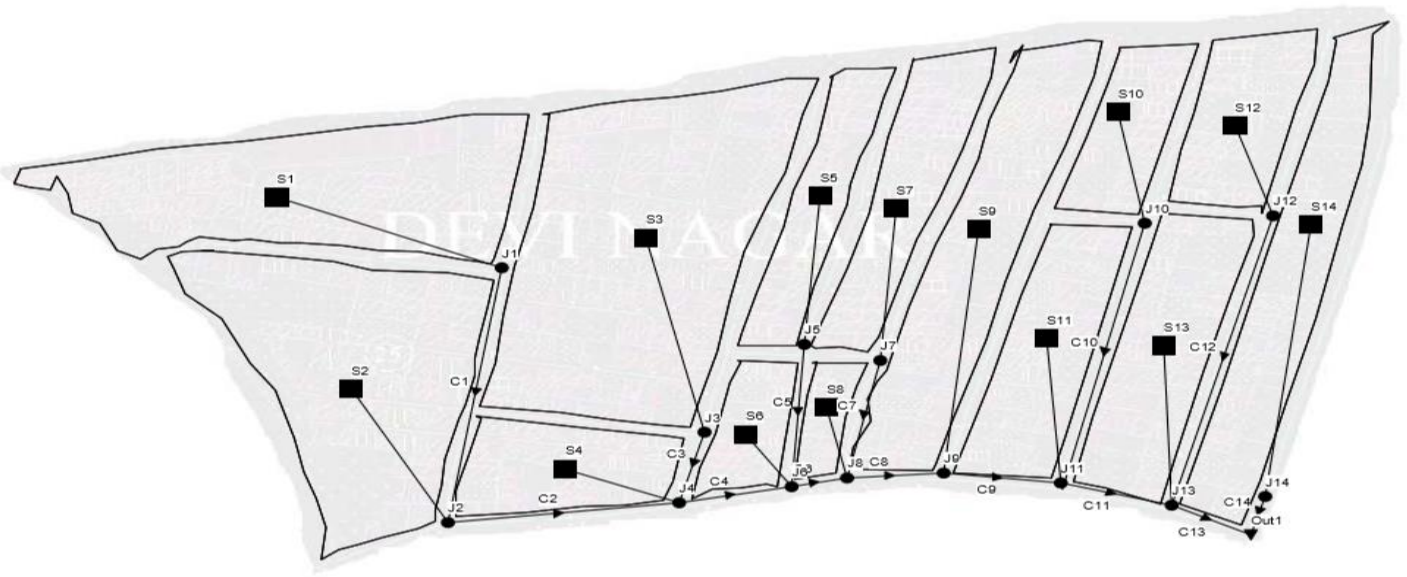

Figure-1 Layout of study area in SWMM

\section{STUDY AREA}

The area considered in present study is Devinagar in the vicinity of Vijayawada city. The Geographic location of the area is is $16^{\circ} 53$ ' $28^{\prime} ' \mathrm{~N}$ latitude and $80^{\circ} 64^{\prime} 31^{\prime}$ ' E longitude. The area is about $2.5 \mathrm{sq} . \mathrm{km}$ which is situated on the banks of budameru canal. The research area is situated on North-Eastern side of Vijayawada city. The area is situated on an altitude $20.5 \mathrm{~m}$ to $23 \mathrm{~m}$ above the mean sea level. The area is receiving average annual rainfall of about $1000 \mathrm{~mm}$ to $1100 \mathrm{~mm}$ for 2017 and 2016 rainfall event. Temperature here ranging from $28^{\circ} \mathrm{C}$ to $38^{\circ} \mathrm{C}$, with average temperature of 34 ${ }^{\circ} \mathrm{C}$.

The data required was drawings of storm water network, dimensions of system and Rainfall data. The $1 \mathrm{hr}$ interval rainfall data for 2017 rainfall event was collected from Andhra Pradesh State Disaster management Authority, drainage details and present drainage network data is collected from Amravati Development Corporation. The Drainage data will be shown in AutoCAD with various features of the catchment.

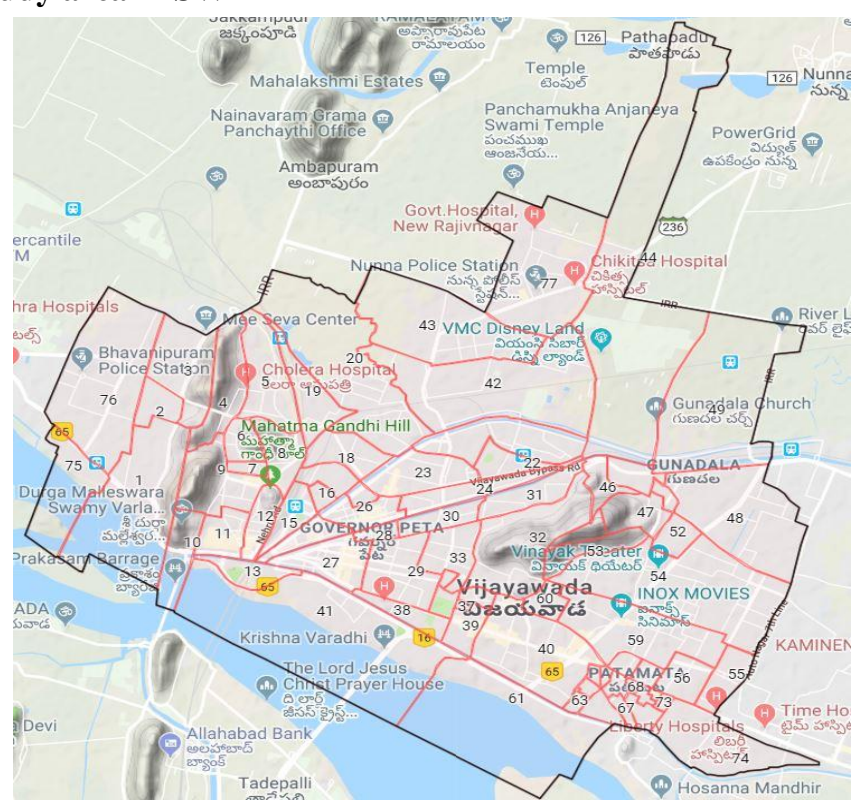

\& outfalls are required. The study area is subdivided into 14 sub catchments, 14 Junction nodes, 14 Conduit links, and one Outfall. 
The Establishment of SWMM develops from stage to stage as varies, first we have to Import the AutoCAD map and snip the Design area, then check out the model parameters and implement drawing objects.

Make sure the network presentation of each sub catchment to the outfall through conduit and junction is clear. In case of object parameter set up provide the area for various sub Fig - 2 Study area representation in Google map catchments, provide junction node Invert elevation with the help of mean sea level values of the study area. Implement circular conduit to the study area by providing $1 \mathrm{~m}$ depth. In case of the Rain gage parameters the rainfall data is observed in the h:m format. From the rainfall event, the data should be entered properly on the basis of hourly data.

Table-1 Various Sub catchments Details

\begin{tabular}{|c|c|c|c|c|c|c|}
\hline Sub catchment & Area (Acres) & Width (m) & N- Imp & N-Perv & Average slope \% & Imperviousness (\%) \\
\hline $\mathrm{S} 1$ & 4.26 & 452 & 0.01 & 0.1 & 2 & 92 \\
\hline S2 & 4.32 & 408 & 0.01 & 0.1 & 2.5 & 90 \\
\hline S3 & 6.31 & 508 & 0.01 & 0.1 & 3.2 & 85 \\
\hline S4 & 1.53 & 340 & 0.01 & 0.1 & 3 & 87 \\
\hline S5 & 1.45 & 100 & 0.01 & 0.1 & 4.5 & 85 \\
\hline S6 & 0.82 & 120 & 0.01 & 0.1 & 4 & 92 \\
\hline S7 & 1.85 & 122 & 0.01 & 0.1 & 2.5 & 91 \\
\hline S8 & 0.43 & 100 & 0.01 & 0.1 & 3 & 85 \\
\hline S9 & 3.16 & 220 & 0.01 & 0.1 & 3.5 & 76 \\
\hline S10 & 1.14 & 190 & 0.01 & 0.1 & 4.2 & 85 \\
\hline S11 & 2.16 & 220 & 0.01 & 0.1 & 3.3 & 83 \\
\hline S12 & 1.41 & 225 & 0.01 & 0.1 & 4 & 90 \\
\hline $\mathrm{S} 13$ & 2.22 & 240 & 0.01 & 0.1 & 2.8 & 84 \\
\hline S14 & 2.82 & 180 & 0.01 & 0.1 & 1.5 & 88 \\
\hline
\end{tabular}

\section{A. MODEL SETUP}

In the present study, Devinagar area was modelled using Storm Water Management Model the version used is EPA SWMM 5.1 software. For simulating the model, sub catchment, conduit, junction, rainfall, land use map for time series editor.

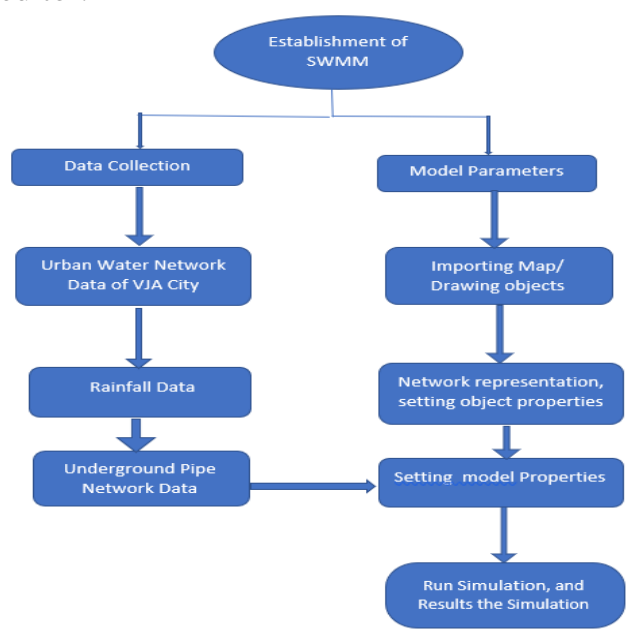

\section{RESULT AND DISCUSSION}

The Peak runoff, water elevation profile, outlet inflow and design of sewer were simulated by using SWMM. The selected area is divided into various sub catchments, designed with proper sewer lines and efficient slope at each junction node. It is observed that the SWMM has generated the peak runoff for the three different extreme rainfall events of Aug 28, Sept 5 and Oct 12 - 2017 respectively. These results help in understanding the Rainfall Runoff of the sub catchments with respect to various rainfall events.

From the Table 2 it is concluded that simulation results of Sept 5 extreme rainfall event shows that maximum flooding occurring at S1, S2, S3, S9 sub catchments. 


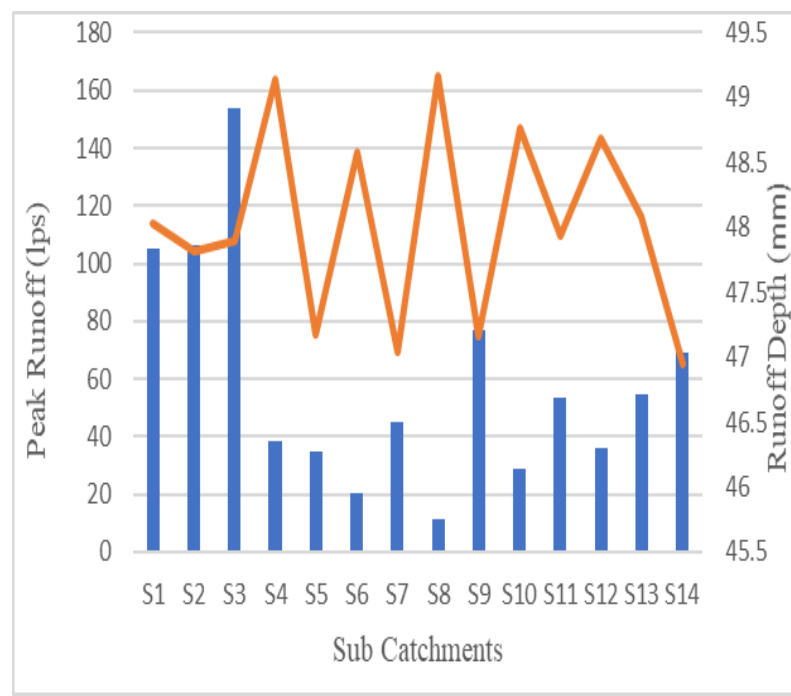

Fig-4 Sub catchments Runoff for Sept 5 rainfall event

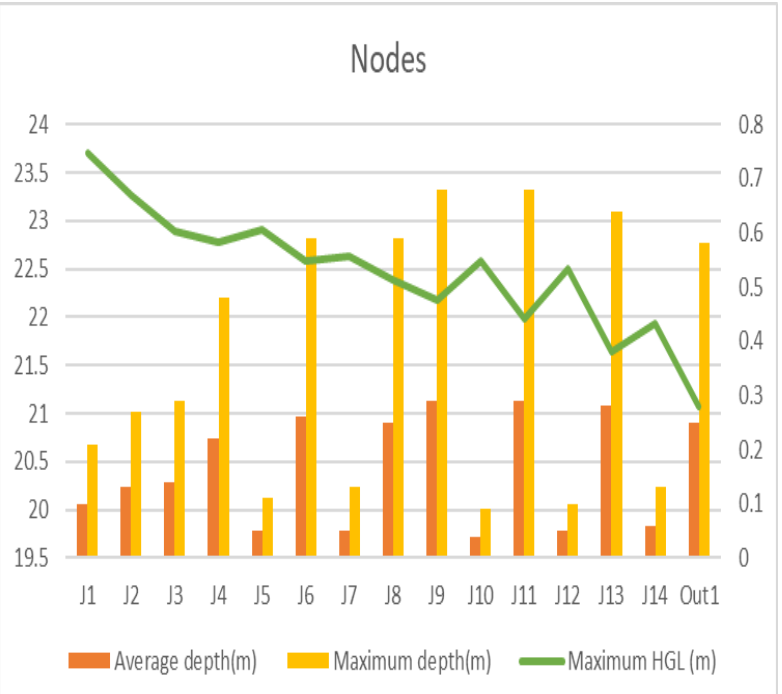

Fig-5 Hydraulic Gradient line Vs Node Depth

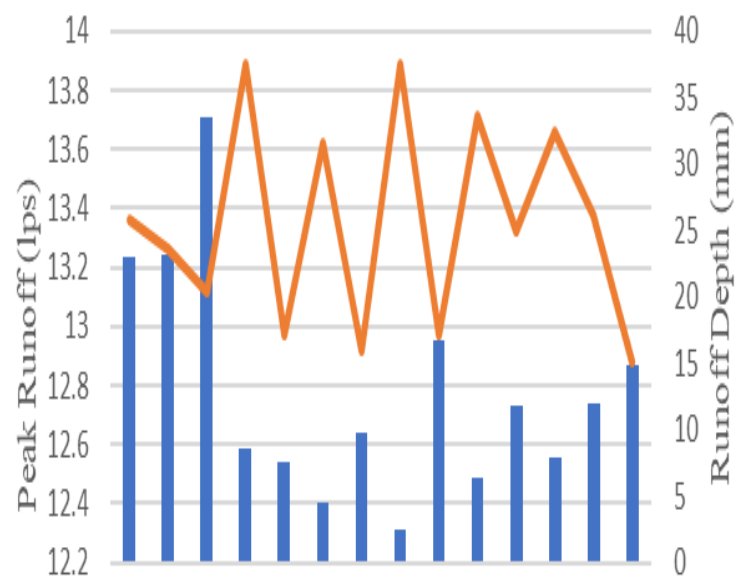

S1 S2 S3 S4 S5 S6 S7 S8 S9 S10S11S12 S13\$14

Sub Catchment

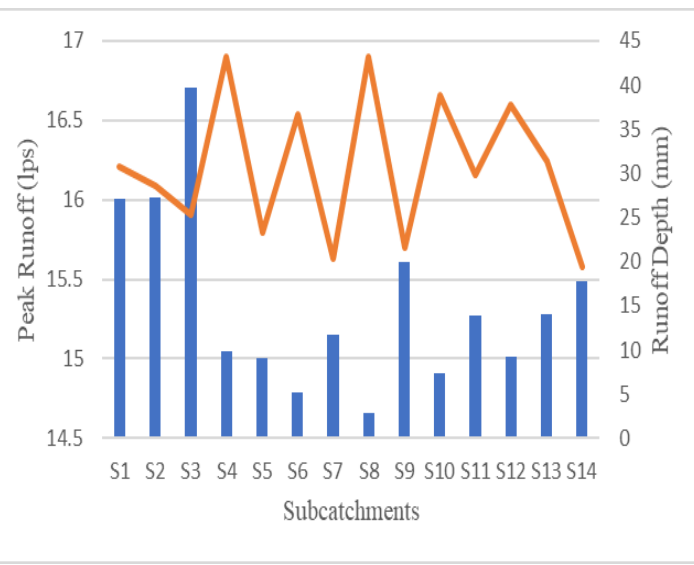

Fig-7 Sub catchments Runoff for Aug 28 rainfall event

\section{A. Profile Plot}

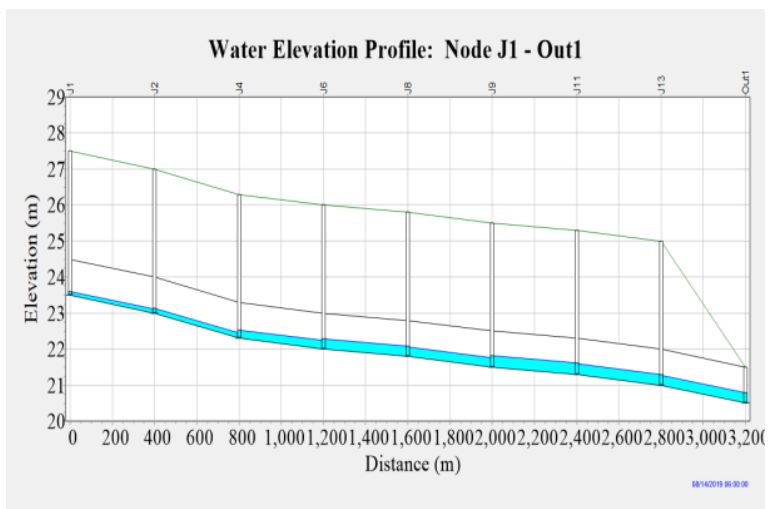

Fig-8 Water Elevation Profile

Water Elevation Profile plots between Distance and Elevation between each Junction node is made in the model. The Fig 8 shows the decrease in level from node $\mathrm{J} 1$ to Out1. This states that there is no water logging by providing minimum invert elevation.

Table - 2 Node depth Values for various Junctions

\begin{tabular}{|c|c|c|c|}
\hline Node & $\begin{array}{c}\text { Average } \\
\text { depth(m) }\end{array}$ & $\begin{array}{c}\text { Maximum } \\
\text { depth(m) }\end{array}$ & $\begin{array}{c}\text { Maximum } \\
\text { HGL (m) }\end{array}$ \\
\hline J1 & 0.1 & 0.1 & 23.71 \\
\hline J2 & 0.13 & 0.13 & 23.27 \\
\hline J3 & 0.14 & 0.14 & 22.89 \\
\hline J4 & 0.22 & 0.22 & 22.78 \\
\hline J5 & 0.05 & 0.05 & 22.91 \\
\hline J6 & 0.26 & 0.26 & 22.59 \\
\hline J7 & 0.05 & 0.05 & 22.63 \\
\hline J8 & 0.25 & 0.25 & 22.39 \\
\hline J9 & 0.29 & 0.29 & 22.18 \\
\hline J10 & 0.04 & 0.04 & 22.59 \\
\hline J11 & 0.29 & 0.29 & 21.98 \\
\hline J12 & 0.05 & 0.05 & 22.5 \\
\hline J13 & 0.28 & 0.28 & 21.64 \\
\hline J14 & 0.06 & 0.06 & 21.93 \\
\hline Out1 & 0.25 & 0.25 & 21.08 \\
\hline
\end{tabular}

Fig-6 Sub catchments Runoff for Oct 12 rainfall event

Retrieval Number: B3928129219/2019@BEIESP

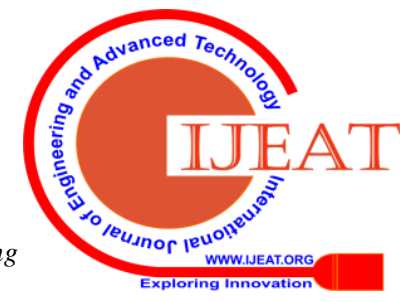


Node depths for various junctions are shown in Table-2. This understands about Average depth, Maximum depth for the different junctions. Hydraulic gradient line for the entire section is almost same with minimum difference. These values help in determining proper flow by providing suitable slope. Link flow for various sections is shown in Table-3 helps in understanding about Maximum flow for each conduit. Conduit C13 has maximum discharge because the runoff arises from various conduits, this Link leads to Outfall. This flow helps in design of cross section of conduits.

Table - 3 Link Flow at various Conduits

\begin{tabular}{|c|c|c|c|c|}
\hline Link & $\begin{array}{c}\text { Maximum } \\
\text { flow (lps) }\end{array}$ & $\begin{array}{c}\text { Max } \\
\text { Velocity } \\
(\mathrm{m} / \mathrm{s})\end{array}$ & Full Flow & $\begin{array}{c}\text { Full } \\
\text { depth }\end{array}$ \\
\hline C1 & 107.4 & 0.95 & 0.1 & 0.21 \\
\hline C2 & 211.58 & 1.27 & 0.16 & 0.27 \\
\hline C3 & 156.85 & 0.88 & 0.18 & 0.29 \\
\hline C4 & 404.08 & 1.11 & 0.47 & 0.48 \\
\hline C5 & 35.55 & 0.82 & 0.03 & 0.11 \\
\hline C6 & 454.27 & 0.98 & 0.65 & 0.59 \\
\hline C7 & 45.37 & 0.83 & 0.04 & 0.13 \\
\hline C8 & 501.85 & 1.16 & 0.59 & 0.55 \\
\hline C9 & 557.97 & 1.01 & 0.8 & 0.68 \\
\hline C10 & 29.17 & 0.9 & 0.02 & 0.09 \\
\hline C11 & 625.8 & 1.2 & 0.73 & 0.64 \\
\hline C12 & 36.64 & 1 & 0.02 & 0.1 \\
\hline C13 & 697.85 & 1.49 & 0.63 & 0.58 \\
\hline C14 & 69.72 & 1.15 & 0.04 & 0.13 \\
\hline
\end{tabular}

The Table-4 depicts about the maximum surface runoff for each sub catchment. it is observed that maximum flooding has occurred at S1, S2, S3, S9.

Table - 4 Sub catchment Runoff

\begin{tabular}{|c|c|c|}
\hline Sub catchment & Area (Acres) & $\begin{array}{c}\text { Peak Runoff } \\
\text { (lps) }\end{array}$ \\
\hline S1 & 4.26 & 105.29 \\
\hline S2 & 4.32 & 106.11 \\
\hline S3 & 6.31 & 153.91 \\
\hline S4 & 1.53 & 38.57 \\
\hline S5 & 1.45 & 34.89 \\
\hline S6 & 0.82 & 20.37 \\
\hline S7 & 1.85 & 44.98 \\
\hline S8 & 0.43 & 11.2 \\
\hline S9 & 3.16 & 76.9 \\
\hline S10 & 1.14 & 28.8 \\
\hline S11 & 2.16 & 53.48 \\
\hline S12 & 1.41 & 35.84 \\
\hline S13 & 2.22 & 54.526 \\
\hline S14 & 2.82 & 68.81 \\
\hline
\end{tabular}

\section{CONCLUSION}

Present study modelled the one-dimensional drainage network for the Devinagar area using SWMM model for simulating the urban rainfall runoff rate. The data required to design the model is collected from Amravati Development Corporation and Andhra Pradesh State Disaster Management Authority. From this model it is observed that SWMM is used for well-planned systematic drainage system and for closed channels. SWMM is also used in simulating the design for ungauged catchment. The result is generated from the three extreme one-year hourly rainfall event during 2017. Simulation results of one-year return period design storm shows that maximum flooding occurring at J2, J4, J6, J8, J9,
J11, J13- 104, 210, 403, 453, 501, 560, 630, 701 lps nodes. Some conduits C2, C3, C4, C6, C8, C9, C11 and C13, has 212, 157, 405, 454, 502, 557, 625 and 698 lps of maximum flow. The peak Runoff for Sub catchments are S1, S2, S3, S9 are 105, 106, 153 and 77 lps respectively. In this model, design depth and peak flow are also simulated. From the analysis of various literature surveys, it is observed that heavy rainfall occurring for limited duration is the cause for major floods in the urban areas which results in waterlogging throughout the region. From these results designing and analysis of the drains can be accompanied thus, flash flood prevention and forecasting can be achieved. SWMM is known as user friendly software because of the variables and model parameters. For simulation of urban drainage system along with SWMM we can use MIKE URBAN, HEC-RAS, ICPR, Hydro CAD etc. For manual calculations Rational method is the best for calculating Rainfall rate.

\section{ACKNOWLEDGEMENT}

This work is supported by Andhra Pradesh Capital Region Development Authority office (APCRDA), Environment protection Agency (EPA) for providing free access to storm water management model (SWMM) and Andhra Pradesh State Disaster Management Authority for providing hourly rainfall data. Special acknowledgements to Sri K. Suresh Babu, manager of town planning of Vijayawada, for providing the necessary data.

\section{REFERENCES}

1. Laddimath, R. S. (2016). Sustainable Development of Storm Water Management using SWMM for Bhagyanagar, Belagavi. 3(02), 488-493.

2. Saini, S. S., Kaushik, S. P., \& Jangra, R. (2016). Flood-risk assessment in urban environment by geospatial approach: a case study of Ambala City, India. Applied Geomatics, 8(3-4), 163-190. https://doi.org/10.1007/s12518-016-0174-7

3. Of, M., \& On, E. (2005). Impact of Weather on Urban Freeway Traffic Management, (August).

4. Wanniarachchi, S. S., \& Wijesekera, N. T. S. (2012). Using SWMM as a Tool for Floodplain Management in Ungauged Urban Watershed. Engineer: Journal of the Institution of Engineers, Sri Lanka, 45(1).

5. Mugisha, F. (2015). Modelling and assessment of urban flood hazards based on end-user requirements. Kigali-Rwanda. 83.

6. Of, M., \& On, E. (2005). Impact of Weather on Urban Freeway Traffic. Management, (August).

7. Agarwal, S., \& Kumar, S. (2019). Applicability of SWMM for Semi Urban Catchment Flood modeling using Extreme Rainfall Events. International Journal of Recent Technology and Engineering, 8(2).

8. Swathi, V., Srinivasa Raju, K., \& Singh, A. P. (2018). Application of Storm Water Management Model to an Urban Catchment. 175-184. https://doi.org/10.1007/978-981-10-5801-1_13

9. Bisht, D. S., Chatterjee, C., Kalakoti, S., Upadhyay, P., Sahoo, M., \& Panda, A. (2016). Modeling urban floods and drainage using SWMM and MIKE URBAN: a case study. Natural Hazards, 84(2), 749-776. https://doi.org/10.1007/s11069-016-2455-1

10. Wanniarachchi, S. S., \& Wijesekera, N. T. S. (2012). Using SWMM as a Tool for Floodplain Management in Ungauged Urban Watershed. Engineer: Journal of the Institution of Engineers, Sri Lanka, 45(1).

11. Shen, J., \& Zhang, Q. (2015). Parameter estimation method for SWMM under the condition of incomplete information based on GIS and RS. Electronic Journal of Geotechnical Engineering, 20(14), 6095-6108.

12. Del Giudice, G., \& Padulano, R. (2016). Sensitivity Analysis and Calibration of a Rainfall-runoff Model with the Combined Use of EPA-SWMM and Genetic Algorithm. Acta Geophysica, 64(5), 1755-1778. 
13. Surwase, T., \& Manjusree, P. (2019). Urban Flood Simulation -a Case Study of Hyderabad city. National Conference on Flood Early Warning for Disaster Risk Reduction, (June), 133-143.

14. Bhowmick, S., Dey, P. D. A., \& Khan, S. M. (2018). Assessment of Storm Water Runoff with Arc-Swat and Swmm in Mymensingh District. 2018(December), 19-21.

15. Naeimi, G., \& Safavi, H. R. (2019). Integrated Stormwater and Groundwater Management in Urban Areas, a Case Study. International Journal of Civil Engineering, 17(8), 1281-1294.

16. Reddy, M., \& Asadi, S. S. (2019). An Analysis of Changing Economic Trends and Rapid Urbanisation Complicate Solid Waste Management. (6), 741-746.

17. Babu, K. V. S., Reddy, K. R., Kumar, K. S., \& Vishwanadham, P. K. (2019). Water Resources Development and Management in Sub Basin using Geospatial Technologies : A Case Study. (6), 639-642.

18. Kumar, P. S., Praveen, T. V, \& Prasad, M. A. (2015). Simulation of rainfall runoff using RS and GIS - A case study Rainfall-Runoff Modelling using Modified NRCS-CN, RS and GIS -A Case Study. (January 2017).

19. Agarwal, S., Patil, J. P., Goyal, V. C., \& Singh, A. (2018). Assessment of Water Supply-Demand Using Water Evaluation and Planning (WEAP) Model for Ur River Watershed, Madhya Pradesh, India. Journal of The Institution of Engineers (India): Series A https://doi.org/10.1007/s40030-018-0329-0

20. Agarwal, S., \& Kumar, S. (2019). Applicability of SWMM for semi Urban Catchment Flood modeling using extreme Rainfall Events. (2), 245-251. https://doi.org/10.35940/ijrte.A3169.078219

21. Tummala, R., Asadi, S. S., \& Chandra, D. S. (2019). An Integrated Approach for Municipal Solid Waste Management: a Model Study from Vijayawada. (6), 804-808.

22. Devi, K. N. V. R., Ramana, R. V., Rao, Y. R. S., \& Kumar, S. (2019). Development of Data Driven Rainfall - Runoff Model for the Sarada River Basin. (6), 508-512.

23. Pradesh, A., Chilukuri, S. K., Chandra, D. S., \& Asadi, S. S. (2019) Assessment of Ground Water Quality Near Muncipal Dump Site and Estimation of Water Quality Index by using Weighted Arithmetic Method Tenali, Guntur District. (6), 125-129.

24. Venkata, Y. R., Chandra, S., \& Aravindan, A. (2019). Assesment of Ground Water Quality Near Muncipal Waste Dumpyard in Kanuru Vijayawada , Andhra Pradesh , India. (6), 266-269.

25. H, L. K. C., Chandra, D. S., \& Asadi, S. S. (2019). Assessment of Water Quality Changes in Krishna River of Andhrap radesh Through Geoinformatics. (6), 737-740.

\section{AUTHORS PROFILE}

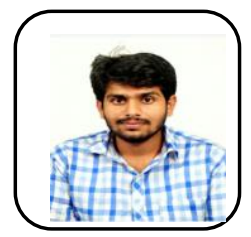

D. Girish is pursuing B.Tech (IV th Year) from Civil Engineering Department, Koneru Lakshmaiah Education Foundation.

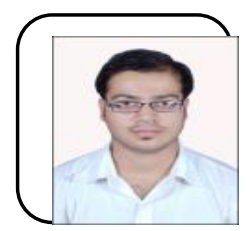

Sunny Agarwal has completed Integrated M.Tech in Water Engineering and Management from Central University of Jharkhand, Ranchi. He is pursuing Ph.D. and working as Assistant Professor at KLEF, Civil Dept., Guntur, A.P., India. He has published three research papers one in International referred Journal (The Institution of Engineers: Series A-Springer) and other two in International Journal of Recent Technology and Engineering (IJRTE). Also, he has published one book in Lambert Academic Publishing. His area of interest is Urban Flooding, Hydrological modeling, RS \& GIS applications etc. He is having lifetime membership of ISRD (International Society for research and development) and IAENG (International Association of Engineers). 